\title{
Pendidikan Kesehatan Latihan Range Of Motion Aktif dan Pasif
}

\author{
Rino $\mathbf{M}^{\mathbf{1}}$, Jufri Al Fajri ${ }^{2}$ \\ ${ }^{1,2}$ Program Studi Profesi Ners, STIKes Baiturrahim Jambi \\ Email : Rino.malvino20@yahoo.com
}

Submitted :01/11/2021 Accepted: 03/11/2021 Published: 19/11/2021

\begin{abstract}
In Indonesia, the number of fracture surgeries by the end of 2017 had reached $27.9 \%$ of the total types of surgery. The prevalence of fractures is quite high, namely the incidence of fractures in the extremities which is around $46.2 \%$. Non-pharmacological management is physiotherapy to reduce pain, maintain, increase muscle and joint strength with Range of Motion (ROM). This community service aims for patients and families to know and understand about active and passive ROM movements. Extension methods using demonstrations, lectures and leaflets. This community service is followed by families and patients who experience mobility barriers due to fractures who have returned home at the Muara Kumpeh Health Center area. The time of service was carried out in July 2020 with a total of 15 people. The results of this community service after the team carried out community service activities, patients and families who attended began to understand and understand how to move ROM in the lower extremities
\end{abstract}

Keywords: health education, fracture, ROM

Abstrak
Di Indonesia angka operasi fraktur hingga akhir tahun 2017 telah mencapai 27,9\% dari total keseluruhan jenis operasi. Prevalensi fraktur yang cukup tinggi yaitu insiden fraktur pada ekstremitas yakni sekitar 46,2\%. Penatalaksanaan non farmakologi yaitu fisioterapi untuk mengurangi nyeri, mempertahankan, meningkatkan kekuatan otot dan sendi dengan Range of Motion (ROM). Pengabdian kepada masyarakat ini bertujuan agar pasien dan keluarga dapat mengetahui dan memahami tentang cara gerakan ROM aktif maupun pasif. Metode penyuluhan dengan menggunakan demonstrasi, Ceramah dan Leaflet. Pengabdian kepada masyarakat ini diikuti Keluarga dan pasien yang mengalami hambatan mobilitas karena fraktur yang sudah pulang kerumah bertempat di wilayah Puskemas Muara Kumpeh. Waktu pengabdian dilakukan pada bulan Juli 2020 dengan jumlah 15 orang. Hasil dari pengabdian kepada masyarakat ini setelah tim melaksanakan kegiatan pengabdian masyarakat pasien dan keluarga yang hadir mulai mengerti dan memahami tentang cara gerakan ROM pada ektremitas bawah.

Kata kunci: fraktur, pendidikan kesehatan, ROM

\section{PENDAHULUAN}

Pembedahan atauoperasi merupakan tindakan pengobatan dengan menggunakan teknik invasif dimana dilakukan sayatan pada bagian tubuh yang akan ditangani dan diakhiri dengan penutupan dengan jahitan luka. Tindakan pembedahan bertujuan untuk menyelamatkan nyawa, mencegah kecacatan dan komplikasi (Safitri, 2015).

Data World Health Organization (WHO) (2018) menunjukkan bahwa selama lebih dari satu abad perawatan bedah sudah menjadi komponen penting dari perawatan kesehatan di seluruh dunia. Diperkirakan 234, 2 juta prosedur operasi dilakukan setiap tahun (Safitri,
2018). Tindakan pembedahan atau operasi terbanyak di rumah sakit seluruh dunia adalah akibat insiden kecelakaan, yaitu operasi fraktur dengan persentase $35,6 \%$ dan sisanya operasi kasus lainnya.

Fraktur adalah terputusnya konstinuitas tulang dan ditentukan sesuai jenis dan luasnya (Anita, 2015). Fraktur dibagi atas fraktur terbuka dan fraktur tertutup. Fraktur terbuka merupakan suatu fraktur dimana terjadi hubungan dengan lingkungan luar melalui kulit. Fraktur tertutup adalah fraktur dimana kulit tidak tertembus oleh frakmen tulang, sehingga tempat fraktur tidak tercemar oleh lingkungan diluar kulit (Permana, 2015). 
Fraktur di Indonesia menjadi penyebab kematian terbesar ketiga di bawah penyakit jantung koroner dan tuberculosis. Kasus fraktur yang disebabkan oleh cedera antara lain karena terjatuh, kecelakaan lalulintas dan trauma benda tajam atau tumpul. Kecenderungan prevalensi cedera menunjukkan kenaikan dari 7,5 \% pada tahun 2017 menjadi 8,2\% padatahun 2018 (Kemenkes RI, 2018).

Di Indonesia angka operasi fraktur hingga akhir tahun 2017 telah mencapai 27,9\% dari total keseluruhan jenis operasi. Prevalensi fraktur yang cukup tinggi yaitu insiden fraktur pada ekstremitas yakni sekitar 46,2\% (Depkes RI, 2017). Hal ini dibuktikan dengan adanya kecenderungan peningkatan tindakan operasi bedah bagian ekstremitas di beberapa rumah sakit dari tahun ke tahun, yakni sekitar delapan juta orang mengalami kejadian fraktur ekstremitas dengan jenis fraktur yang berbeda dan penyebab yang berbedayang dapat terjadi pada tulang lengan atas, lengan bawah, tungkai atas, tungkai bawah, tangan dan kaki (Windiarto, 2016).

Berdasarkan 34 Provinsi yang ada di Indonesia, tindakan operasi fraktur ekstremitas paling tinggi ada pada Provinsi Bali (3.065), disusul setelahnya DKI Jakarta (2.780), Jawa Timur (2.655), Jawa Tengah (2.576) dan Jambi (2.443) (Depkes RI, 2018). Dari 19 Kabupaten/Kota yang ada di Jambi, Kota Jambi merupakan daerah yang persentase rumah sakitnya paling banyak melakukan tindakan operasi fraktur ekstremitas (20,3\%), disusul setelahnya Dharmasraya (16,2\%) dan Pasaman Barat $(11,5 \%)$ yang telah mengalami kenaikan $1,3 \%$ bila dibandingkan dengan tahun sebelumnya (Riskesdas, 2018).

Banyak dampak negatif dari kejadian fraktur ekstremitas. Menurut Oktasari (2013), dari 2.700 orang mengalami insiden fraktur ekstremitas, $56 \%$ penderita mengalami kecacatan fisik, 24\% mengalami kematian, $15 \%$ mengalami kesembuhan dan 5\% mengalami gangguan psikologis atau depresi terhadap adanya kejadian fraktur. Kerusakan frakmen tulang ekstremitas memberikan menifestasi pada hambatan mobilisasi fisik dan akan diikuti dengan adanya spasme otot yang memberikan menifestasi deformitas pada ekstremitas yaitu pemendekan, apabila kondisi ini berlanjut tanpa dilakukan intervensi yang optimal maka akan memberikan risiko terjadinya malunion pada tulang yang mengalami fraktur tersebut.

Pendidikan kesehatan sangat penting khususnya dalam penatalaksanaan non farmakologi untuk mengurangi nyeri dan mempertahankan/meningkatkan kekuatan otot dan sendi yaitu dengan Range of Motion (ROM). ROM merupakan salah satu indicator fisik yang berhubungan dengan fungsi pergerakan. Penatalaksanaan non farmakologi yaitu fisioterapi untuk mengurangi nyeri dan mempertahankan atau meningkatkan kekuatan otot dan sendi yaitu dengan Range of Motion (ROM). ROM merupakan salah satu indicator fisik yang berhubungan dengan fungsi pergerakan. Menurut Insiyah (2015), ROM dapat diartikan sebagai pergerakan maksimal yang dimungkinkan pada sebuah persendian tanpa menyebabkan rasa nyeri. ROM merupakan kegiatan yang penting dalam pemulihan kekuatan otot dan sendi post operasi untuk mencegah komplikasi lebih lanjut

Latihan ROM adalah latihan yang dilakukan untuk mempertahankan atau memperbaiki tingkat kesempurnaan kemampuan menggerakkan persendian secara normal danlengkap untuk meningkatkan massa otot dan tonus otot (Potter \& Perry, 2005 dalam Wiharja, 2016).ROM adalah latihan yang memungkinkan terjadinya kontraksi danpergerakan otot, dimana klien menggerakkan masing- masing persendiannya sesuai gerakan normal baik secara aktif ataupun pasif (Ridha \& Putri, 2015). ROM aktif lebih memberikan pengaruh dibandingkan ROM pasif sebesar 3,2x. hal ini dikarenakan pada ROM aktif pasien dapat lebih sering dan mandiri dalam melakukan latihan dengan nyaman serta terhindar dari rasa nyeri. Anita (2018) juga mengatakan bahwa mobilisasi dini dengan ROM aktif adalahsalahsatufaktorkuncidalamperawatanpasi enpost operasi fraktur ekstremitas.

Menurut Usyaira (2015), melakukan tindakan ROM aktif pada pasien post operasi fraktur ekstremitas sangat mempengaruhi dengan tingkat kesembuhan pasien. Dilakukannya ROM secara rutin dapat mempertahankan mobilitas sendi dan jaringan ikat, meminimalisir efek dari pembentukan kontraktur, mempertahankan elastisitas mekanis dari otot, membantu kelancaran sirkulasi, meningkatkan pergerakan synovial untuk 
nutrisi tulang rawan serta difusi persendian, menurunkan atau mencegah rasa nyeri, membantu proses penyembuhan pascacedera dan operasi dan membantu mempertahankan kesadaran akan gerak dari pasien. Untuk mendapatkan hasil yang maksimal, ROM harus diulang sekitar 8 kali dan dikerjakan minimal 2 kali sehari selama minimal 3 hari berturut-turut dan dapat dilakukan hari ke 2 setelah operasi.

Berdasarkan studi pendahuluan yang dilakukan oleh mewawancarai 5 orang pasien post operasi fraktur ekstremitas, didapati bahwa 3 dari 5 orang pasien mengatakan masa pemulihan setelah operasi terasa lambat, lebihdari 3 hari ekstremitas bekasoperasibaru dapat digerakkan. 2 dari 5 orang pasien mengatakan tidak melakukan ROM aktif, Latihan ROM hanya dilakukan saat ada perawat yang membantu saja. Berdasarkan hasil observasi yang dilakukan oleh peneliti di hari yang sama, peneliti juga menemukan bahwa belum ada satupun pasien melakukan ROM aktif (mandiri). 3 dari 5 orang pasien memiliki kekuatan sendi dan otot dengan rentang nilai 1 (skala 0-5).

Berdasarkan latar belakang dan fenomena yang ditemukan oleh peneliti, maka peneliti tertarik untuk melakukan penelitian yang berjudul "Pengaruh range of motion aktif terhadap pemulihan kekuatan otot dan sendi pasien post op fraktur ekstremitas di Wilayah kerja puskemas Muara Kumpeh”.

\section{TARGET DAN LUARAN}

\section{Target}

a. Mengidentifikasi pengetahuan ROM dalam menghadapai Fraktur Ekstremitas

b. Meningkatnya pemahaman pasien tentang ROM

\section{Luaran}

Luaran Dari Pengabdian Kepada Masyarakat Tentang Pendidikan Kesehatan Latihan Range Of Motion Aktif Dan Pasif diharapkan dapat mengetahui dan memahami tentang Gerakan ROM, tujuan dari Gerakan ROM, prinsip Gerakan ROM, klasifikasi Gerakan ROM, dan cara Gerakan ROM baik aktif maupun pasif.

\section{METODE PELAKSANAAN}

Metode pelaksanaan dimulai dari mengurus surat Izin pengabdian masyarakat,
Memberikan penyuluhan dengan mengggunakan metode diskusi, tanya jawab. Pelaksanaan Pengabdian Kepada Masyarakat ini dilakukan di wiliayah puskemas muara kumpeh Pada Januari 2020. Media yang digunakan pada pengabdian ini adalah LCD, Laptop, power point,Leaflet.

\section{HASIL DAN PEMBAHASAAN}

Hasil dari kegiatan pengabdian kepada masyarakat ini adalah Setelah tim melaksanakan kegiatan pengabdian masyarakat pasien/masyarakat yang hadir dapat mengetahui, memahami dan mampu mempraktekkan/ mendemonstrasikan cara gerakan ROM baik aktif maupun pasif pada ektremitas bawah.

Fraktur adalah terputusnya kontinuitas jaringan tulang dan / atau tulang rawan yang umumnya disebabkan oleh rudapaksa (Sjamsuhidajat, 2015). Fraktur femur adalah suatu patahan pada kontinuitas struktur tulang paha yang ditandai adanya deformitas yang jelas yaitu pemendekan tungkai yang mengalami fraktur dan hambatan mobilitas fisik yang nyata (Muttaqin, 2013). Fraktur dapat terjadi akibat peristiwa trauma langsung, tekanan yang berulang-ulang, dan kelemahan abnormal pada tulang (fraktur patologik) (Salamon, 2010).

Fraktur terbagi atas fraktur komplet, fraktur tidak komplet, fraktur tertutup, fraktur terbuka, dan fraktur patologis. Fraktur bisa terjadi didaerah cranium, thorak, pelvis, anggota gerak atas, dan anggota gerak bawah. Prinsip penanganan fraktur meliputi reduksi, imobilisasi, pengembalian fungsi, dan kekuatan normal dengan rehabilitasi. Reduksi dapat dilakukan secara terbuka maupun tertutup. Reduksi terbuka (open reduksi) dilakukan melalui pembedahan dengan cara memasukkan alat fiksasi berupa plat, screw, wire atau pin kedalam tulang. Fiksasi dapat dilaksanakan secara interna maupun ekterna, tergantung dari bentuk frakturnya (Smeltzer \& Bare, 2012).

Kondisi perkembangan kekuatan otot dan sendi pasien akan berdampak pada lama perawatan. Waktu perawatan Length of stay (LOS) merupakan salah satu indikator penilaian dalam akreditasi sebuah rumah sakit. Semakin lama length of stay maka penilaian terhadap rumah sakit tersebut semakin buruk. Dampak negatif lain yang diakibatkan lamanya 
pemulihan kekuatan otot dan sendi pasien pasca operasi menyebabkan pasien harus berlamalama dalam posisi tirah baring. Posisi tirah baring yang lama akan meningkatkan terjadinya komplikasi yang serius seperti pembentukan suatu thrombus sehingga aliran balik vena mengalami hambatan (Windiarto, 2016).

Faktor pemulihan kekuatan otot dan sendi bagi pasien post op fraktur ekstremitas dapat dilakukan dengan penatalaksanaan farmakologi dan non farmakologi. Penatalaksanaan secara farmakologi dapat dilakukan dengan cara pemberian obat-obatan. Obat farmakologi dapat memberikan efek samping yang jika konsumsi secara berlebihan maka akan menimbulkan terjadinya retensi cairan, alergi dan aritmia jantung. Upaya untuk meminimalkan efek samping farmakologis, maka perlu pendekatan nonfarmakologis (Nuraini, 2016).

Menurut teori yang dikemukakan oleh Smeltzer (2012), latihan rentang gerak bertujuan untuk mempertahankan fleksibilitas dan mobilitas sendi, mengembalikan kontrol motorik, meningkatkan/ mempertahankan integritas sendi dan jaringan lunak, membantu sirkulasi dan nutrisi sinovial dan menurunkan pembentukan kontraktur terutama pada ekstremitas yang mengalami paralisis. Manfaat lain yang didapatkan dari latihan rentang gerak yaitu dapat memaksimalkan fungsi aktifitas kehidupan sehari-hari, mengurangi atau menghambat nyeri, mencegah bertambah buruknya sistem neuromuscular, mengurangi gejala depresi dan kecemasan, meningkatkan harga diri, meningkatkan citra tubuh dan memberikan kesenangan.

Muscle spindle merupakan suatu receptor yang menerima rangsang dari regangan otot. Regangan yang cepat akan menghasilkan impuls yang kuat pada muscle spindle. Rangsangan yang kuat akan menyebabkan refleks muscle spindle yaitu mengirim impuls ke spinal cord menuju jaringan otot dengan cepat, menyebabkan kontraksi otot yang cepat dan kuat. Muscle spindle sangat berperan dalam proses pergerakan atau pengaturan motorik (Potter \& Perry, 2005).

Pada klien fraktur mengalami keterbatasan dalam pergerakan, latihan pasif sangat tepat dilakukan dan akan mendapatkan manfaat seperti terhindarnya dari kemungkinan terjadinya gangguan fleksibilitas sendi. Setiap gerakan yang dilakukan dengan rentang yang penuh, maka akan meningkatkan kemampuan bergerak dan dapat mencegah keterbatasan dalam beraktivitas.Latihan rentang gerak yang diberikan dalam penelitian ini cukup mendapat respon yang baik dari responden, keluarga dan petugas Trauma Centre sendiri. Pelaksanaan latihan rentang gerak ini juga didukung dengan pedoman yang disertai gambar, sehingga memudahkan responden dan petugas untk melaksanakannya.

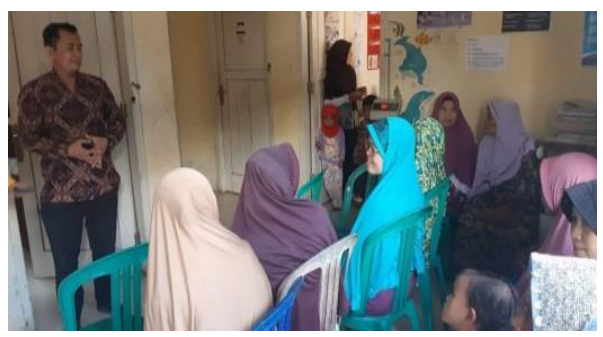

Gambar 1. Pendidikan Kesehatan

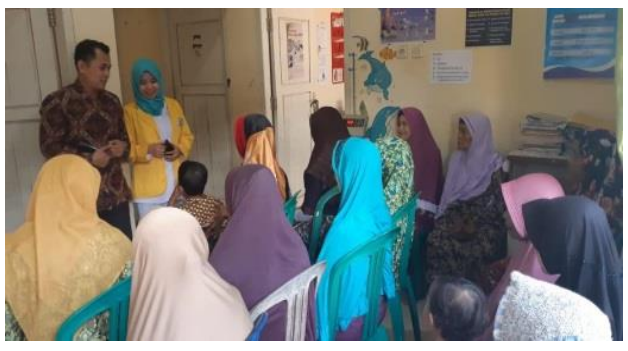

Gambar 2. Pemberian Edukasi pada pasien

\section{KESIMPULAN DAN SARAN}

\section{Kesimpulan}

Setelah tim melaksanakan kegiatan pengabdian masyarakat pasien/masyarakat yang hadir memahami, mempraktekkan/ mendemonstrasikan cara gerakan ROM pada ektremitas bawah.

\section{Saran}

Diharapkan ROM ini menjadi salah satu program yang ditawarkan dan dikenalkan kepada pasien pemulihan kekuatan otot dan sendi pasien post op fraktur ekstremitas di Wilayah kerja puskemas Muara Kumpeh sebagai metode untuk meningkatkan fungsi muskular pada pasien.

\section{UCAPAN TERIMAKASIH}

Terima kasih kepada Bapak Ketua Sekolah Tinggi Ilmu Kesehatan Baiturrahim Jambi yag telah memberikan dana dan Kepala Puskemas Muara Kumpeh yang telah memberikan izin 
memfasilitasi kegiatan pengabdian masyarakat ini.

\section{DAFTAR PUSTAKA}

Aini, M. (2015). Efektivitas Latihan Range Of Motion (ROM) Bahu terhadap Peningkatan ROM pada Pasien Post Mastektomi di RSUP H. Adam Malik Medan. Jurnal Keperawatan USU. 5(3), 980-997

Anita, F. (2015). Pengaruh Latihan Range of Motion terhadap Rentang Gerak Sendi Ekstremitas Atas pada Pasien Pasca Stroke di Makassar. Journal of Islamic Nursing. 3(1), 97-99.

Bowden, (2018). Pediatric nursing procedures. second edition. Philadelphia: Lipincot William and Wilkins.

Depkes RI (2017). Prevalensi Angka Kejadian Fraktur di Indonesia. Jakarta.

Gontung, A.T. (2012). Orthopaedic dan Traumatology Center di Manado "Sustainable Healthcare Architecture" Jurnal UNSRAT. 4(3), 93-102

Hastono, S. P. \& S. (2011). Statistik Kesehatan (1st ed.). Raja Grafindo Persada. Jakarta.

Insiyah, R. (2015). Petingnya Latihan Gerak pada Pasien Fraktur. Rineka Cipta. Jakarta.

Kemenkes RI (2018). Prevalensi Cidera Akibat Kecelakaan di Indonesia. Jakarta.

Murtaqin, R. (2013). Pengaruh ROM terhadap Pencegahan Kecacatan. Rineka Cipta. Jakarta.

Nuraini, D.S. (2016). Perbedaan Slow Deep Breathing dan Diaphragmatic Breathing Terhadap Penurunan Tekanan Darah pada Pasien Hipertensi di RSUD Ambarawa. Jurnal Ilmu Keperawatan dan Kebidanan (JIKK). 6(2), 1-10.

Oktasari, V. (2013). Pengaruh Pendidikan Kesehatan Terhadap Pelaksanaan Rentang Gerak Sendi Aktif Post Operasi pada Pasien Fraktur Ekstremitas di Ruang Bedah Trauma Center RSUP DR. M. Djamil Padang. Jurnal Ners. 9(2), 94102.

Permana, O. (2015). Pengaruh Range Of Motion (ROM) terhadap Intensitas Nyeri pada Pasien Post Operasi Fraktur Ekstremitas Bawah. Jurnal KEMAS. 2(2), 1327-1334.
Purwanti, R. (2015). Pengaruh Latihan Range Of Motion (ROM) Aktif terhadap Kekuatan Otot Pada Pasien Post Operasi Fraktur Humerus di RSUD Dr. Moewardi. GASTER. 10(2), 42-52.

Ridha \& Putri. (2015). Pengaruh Latihan Range Of Motion (ROM) Aktif terhadap Kekuatan Otot Ekstremitas Bawah pada Lansia dengan Osteoarthritis di Wilayah Kerja Puskesmas Koni Kota Jambi. Jurnal Akademika Baiturrahim. 4(2), 4552.

Safitri, U. (2018). Efektifitas ROM Aktif dan Mobilisasi Dini terhadap Kembalinya Peristaltik Usus pada Pasien Post Operasi Abdomen dengan General Anestesi di RSUD Kota Salatiga. Jurnal Ilmu Keperawatan dan Kebidanan (JIKK). $7(2), 67-78$

Sjamsuhidajat, (2015). Buku-ajar ilmu bedah (2nd.). Jakarta: Buku Kedokteran EGC.

Smeltzer, (2012). Buku ajar keperawatanmedikal-bedah brunner \& suddarth (8th, 3rd vol.). Jakarta: Buku Kedokteran EGC

WHO. (2018). Surgery in the World. Philadelpia. Pennsylvania. USA. 